FILOZOFIA

Roč. 74, 2019, č. 6

\title{
HEGEL'S THEORY OF THE EMERGENCE OF SUBJECTIVITY AND THE CONDITIONS FOR THE DEVELOPMENT OF HUMAN RIGHTS
}

JON STEWART, Institute of Philosophy, Slovak Academy of Sciences, Bratislava, Slovakia

STEWART, J.: Hegel's Theory of the Emergence of Subjectivity and the Conditions for the Development of Human Rights

FILOZOFIA, 74, 2019, No 6, pp. $456-471$

Globalization and mass migration have raised anew the question of the nature and origin of human rights. There have been a number of works that seek inspiration on this issue from the philosophy of Hegel. Usually, the primary focus of these works has, naturally enough, been the main statement of Hegel's political philosophy, the Philosophy of Right. Scholars go to this work in search of a principle that can ground human rights in such a way that can be meaningfully used in a political and legal context. This body of literature is important in that it draws attention to this aspect of Hegel's thought and shows how it is relevant for a problem of some topicality today. However, this approach, I wish to argue, takes up the issue at a fairly advanced stage in Hegel's thinking and fails to see some much more fundamental elements in his way of understanding the concept of human rights, specifically, that the very idea of human rights presupposes a philosophical anthropology and a theory of history since human rights as a concept did not always exist. These aspects of Hegel's theory have been generally neglected in the secondary literature on the issue of human rights.

Keywords: Philosophical anthropology - Human rights - Philosophy of history Subjectivity

Globalization and mass migration have raised anew the question of the nature and origin of human rights. Scholars primarily in political theory have been concerned to find some kind of firm grounding for this concept which is so valued in the modern world. There have been a number of works that seek inspiration on this issue from the philosophy of Hegel. ${ }^{1}$ Usually, the primary focus of these works has, naturally enough, been on the main statement of Hegel's political philosophy, the Philosophy of Right. Scholars go to this work in search of a principle that can ground human rights in a way that can be meaningfully used in a political and legal context. These discussions are often closely connected to those concerning Hegel's concept of recognition in the

\footnotetext{
${ }^{1}$ There have been a number of attempts in the secondary literature to return to Hegel for insight on this issue. See Hinchman (1984), Buchwalter (2013), Maletz (1989), Smith (1989), Stillman (1980), Mullender (2003), Douzinas (2002), Butler (2008).
} 
sense that it is necessary that individuals recognize the rights or others or that the state recognize its citizens as individuals who have rights. ${ }^{2}$ This body of literature is important in that it draws attention to this aspect of Hegel's thought and shows how it is relevant for a problem of some topicality today.

However, this approach, I wish to argue, takes up the issue at a fairly advanced stage in Hegel's thinking and fails to see some much more fundamental elements in his way of understanding the concept of human rights. First, the very idea of human rights presupposes a philosophical anthropology. Any statement of inalienable human rights in a sense dictates a specific vision of what a human being is since it is necessary to know what kind of a creature humans are that they can be bearers of such rights. ${ }^{3}$ Second, this also presupposes a theory of history. Human rights as a concept did not always exist. What were the historical circumstances that allowed this concept to arise? It is important to determine when an idea of human beings appeared that allowed for the idea of human rights to arise and take root. Thus, Hegel's theories of philosophical anthropology and philosophy of history are of supreme importance for this topic. These theories can be regarded as antecedent to the question of how to ground human rights, since the latter already assumes their existence and value. But the more fundamental question is how we came to have the concept of human rights in the first place. These aspects of Hegel's theory have been generally neglected in the secondary literature on the issue of human rights. ${ }^{4}$

The broad story that Hegel wants to tell in his Lectures on the Philosophy of History concerns the nature and role of the individual. In traditional cultures the focus tends to be more on the group, with the person being primarily conceived not as an individual but as a part of a larger whole, e.g., the family, clan, tribe, etc. By contrast, in the West, the focus is often more on the individual as such, devoid of any relations to others. Hegel presents a sweeping theory of history that, among other things, seeks to explain this difference in focus between traditional and modern cultures. In this story the idea of what it is to be human grows and develops. His theory can provide some insight into the concept and development of human rights.

In his lectures Hegel presents a theory about the development of not just Western Civilization but world history. The main line of argument concerns broadly what might be conceived as a theory of philosophical anthropology. It attempts to trace the various self-conceptions of people in different cultures as they develop through time. These self-conceptions thus reflect different views of what it is to be human. His thesis is that

\footnotetext{
${ }^{2}$ See, for example, Honneth (1995), Honneth (2012), Taylor and Gutman (1994).

${ }^{3}$ For this reason, the idea of human rights has been criticized for being ideological and not reflecting something that is universal in all human beings. See Ibhawoh (2007), Bricmont (2007).

${ }^{4}$ For a valuable exception to the rule, see Dorfman (2014).
} 
in these one can discern the development of what we today would call "inwardness" or "subjectivity." According to Hegel's view, as human civilization took its first tenuous steps, it had a very limited conception of the individual. Instead, the dominant principle was that of the wider group or people. Only in the course of history did the idea of what we know as individuality begin to emerge. It took millennia for the notion of the individual, with one's own sphere of inwardness, to be recognized and developed. The emergence of this conception of human beings had a sweeping impact on all aspects of culture, such as philosophy, religion, art, and law. It was with this conception that the idea of human rights arose.

Hegel is often conceived as an ethnocentric and Eurocentric apologist, whose theory is intended to justify, among other things, the abuses of European colonization in his own time. ${ }^{5}$ His account of history has thus usually been taken to be a traditional encomium for the virtues of Western civilization. But this interpretation is one-sided. His thinking is dialectical, and so he always strives to find some kind of higher truth or balance between conflicting positions. This includes what might be conceived as the conflict between ancient and modern cultures. In fact, Hegel appreciated and valued certain elements of pre-modern and non-Western cultures.

My thesis in this paper is that the modern idea of human rights could only come about at a specific point in time when the anthropological conception allowed for it. Only when humans came to be regarded as having an inward sphere of subjectivity and being capable of exercising their freedom, did the notion of human rights emerge. Thus the concept of human rights is intimately tied to the conception of a human being that is present. I wish to argue that this view provides some valuable insight into discussions concerning the status and origin of human rights.

\section{The Nature of Truth: Outward or Inward}

Hegel's theory concerns one of the perennial questions of philosophy: what is the truth? The locus of truth can be regarded as something outward or something inward. According to one view, the truth is something external, some fact of the matter out in the world, which is wholly indifferent to one's perception or understanding of it. According to the opposite view, the truths of the external world are only illusory, and the real truth is to be found in the inward sphere, the human heart or the mind of the individual. Taken on their own, these are simply two logical possibilities, which correspond better or worse to our intuitions about the truth in different areas. Most of us probably incline towards the former view in matters of science. When we think of modern astronomical research on, for example, exoplanets, we believe that these are things

\footnotetext{
${ }^{5}$ See, for example, Tibebu (2011), Bernasconi (1998), Bernasconi (2000), Bernasconi (2007), Camara (2005), Hoffheimer (2001), Hoffheimer (2005).
} 
that exist on their own independently of us. They are out there waiting to be discovered and examined. By contrast, we tend to lean towards the subjective view in matters of art, ethics or perhaps religion. When we view a work of art, very different kinds of feelings might be evoked in different observers. The truth of the artwork is not something objective for all to see but rather something subjective, relative to the sensibilities and dispositions of the observer. It is probably fair to say that, for most of us, our intuitions are in some way divided here. There are some areas where the objective model seems to fit best and some where the subjective model does so.

For Hegel, these two logical possibilities correspond to two main periods in the development of world history. The objective locus of truth is the characteristic of the ancient world, whereas the subjective is that of the modern world. In order to appreciate this claim, we need to look briefly at Hegel's theory of historical development.

It should, however, be noted that while these two views might appear at first glance to be a fixed dualism or dichotomy, this is not the case. On the contrary, Hegel's thinking on this point is also dialectical. The goal is not to develop one side to the exclusion of the other. Instead, the trick is to arrive at the proper balance of the two opposing elements. This would involve developing institutions that, on the one hand, promote a sense of community and solidarity (the objective), while, on the other hand, encouraging the development of the inward side of the individual (the subjective).

\section{The Beginning of History: The Outward Sphere of Custom and Tradition}

Science looks at empirical phenomena in the world and tries to understand them by identifying patterns and regularities. Thus it tries to come up with laws or general structures which serve to explain the diverse manifold of the world. In this there are always two elements: the sphere of the empirical, which is that of particularity, and the sphere of the explanation, which are ideas and thus constitute universality. Hegel's doctrine of the Concept (Begriff) demonstrates the constant dialectical interaction between empirical perception and ideas, or between particulars and universals, or Besonderheit and Allgemeinheit. The constant movement from particularity to universality and back is a fundamental feature of human cognition. According to Hegel, these two sides are united in a third Einzelheit, that is, when the particular corresponds to the universal.

These elements appear not just in Hegel's works on metaphysics but also in his philosophy of history. As is well known, Hegel claims that the development of world history displays the gradual realization of the idea of human freedom, which he refers to in a shorthand manner simply as "the Idea." An idea is of course different from the events of history that take place in time and space. ${ }^{6}$ Here we can see the realm of the

\footnotetext{
${ }^{6}$ This is a key methodological point in Kierkegaard's use of Hegel in his early work, The Concept of Irony. See Stewart (2011) and Söderquist (2012).
} 
universal (the idea of freedom) and the realm of the particulars (the actions and events of history). Hegel's philosophy of history has often been criticized for being overly abstract and thus imposing an ideal structure on the chaotic events of history. For example, Kierkegaard rebukes him for not making a more careful study of the historical sources: "Anything like this is effort wasted on Hegel, and when the phenomena are paraded, he is in too much of a hurry and is too aware of the great importance of his role as commander-in-chief of world history to take time for more than the royal glance he allows to glide over them" (Kierkegaard 1989, 222). Thus, for Kierkegaard, Hegel focuses on the universal and neglects the particulars.

But according to Hegel, these two are not radically separated; instead, the Idea can be discerned in these events, and when one takes the bird's eye view of history, it can be seen as developing through the centuries. What he means by this Idea concerns the development of the inward nature of the individual. It is the sense that individuals are rational and can use their rationality to act in accordance with just customs, traditions, and laws. They choose freely to do so since they can recognize their own rationality reflected in these things.

According to Hegel's account, traditional societies and cultures are characterized by the view that the truth dwells in the outward sphere, i.e., in their customs, laws, religion, etc., what Hegel refers to as the realm of Sittlichkeit (Hegel 1991, § 151, p. 195; Hegel 1928 - 1941, vol. 7, p. 233). This conception, he claims, was dominant in ancient China, India, Persia and Egypt. For centuries it also enjoyed a position of unquestioned hegemony in the ancient Greek world. The early Greeks, according to Hegel, lived in harmony with their public customs and religion. The truth was an objective, seemingly verifiable fact that could be found in their practices, ceremonies and traditions every day of their lives. These practices were thought to have a divine sanction and to be completely continuous with the natural world.

Hegel illustrates this with a number of examples from his different lectures. Sophocles' Oedipus the King begins with a terrible plague that afflicts the city of Thebes. Through his patricide and incest, Oedipus has violated not just human laws but also the laws of nature. He has disrupted the harmony that should exist in the universe, according to the laws as set down by the gods. As a result, nature itself reacts in the form of a plague. It is unnatural for crops not to grow, for cattle not to reproduce, and for young and healthy people to die suddenly, but this is what happens. The plague is nature's way of expressing that some infraction has occurred. The prohibitions of patricide and incest are not mere human conventions, but rather facts of nature.

To take another example, in Sophocles' tragedy, Antigone, the lead character insists on the sacred burial rites that surviving family members must give to their deceased. To the mind of Antigone, this is no mere family custom or tradition, but rather 
a fact of nature. The tragic heroine says of the laws of the gods, "Not now, nor yesterday's, they always live, / and no one knows their origin in time" (Sophocles 1960, lines $456-457$, p. 202). ${ }^{7}$ Thus, while we today tend to think of certain laws or customs as mere arbitrary conventions, according to this conception these were fixed natural laws. They were simply facts about the universe, and the personal opinion of individuals played no role in this whatsoever. This line from Antigone is often quoted by scholars in the natural law tradition in jurisprudence.

This is the model of traditional society. Since the truth is found in the external sphere, the desires, inclinations and rights of the individual are not regarded as important or valid. For example, young men are expected to follow in the professions of their fathers, and their own personal views on the matter are irrelevant. Similarly, parents arrange the marriages of their children with an eye towards making strategic alliances with other families, and the feelings of their children who are actually getting married do not matter. In short, the interests of the family are regarded as more important than those of the individual family member. For Hegel, history thus began with this focus on the external sphere of nature and custom, and the principles of individuality, inwardness and subjectivity remained to be discovered.

\section{The Crisis of Custom and Tradition and the Transition to a New Principle}

While the traditional view placed the truth on the side of the objective sphere of nature, Hegel argues that such principles necessarily produce or give rise to their opposites over time. His dialectical method is, of course, characterized by the idea that a specific concept or principle comes to produce its opposite. In his metaphysics in the Science of Logic, as is well known, he argues that the concept of being necessarily presupposes and produces the concept of nothingness, just as the concept of the one presupposes and produces the concept of the many and the concept substance necessarily presupposes and produces the concept of accidents or properties (Hegel 1989, p. 82, pp. $164-170$, 484 -492; Hegel 1928 - 1941, vol. 4, pp. 87 - 88, 192 - 199, 598 - 613). These notions are thus conceptually related, and it is impossible to have the one without the other. The idea of being cannot exist without the idea of nothingness.

So also the ideas of objectivity and subjectivity. While history began with the idea that truth existed in the objective sphere, and the individual played no role in it, over time a new principle arose in opposition to this. According to Hegel, a shift started to take place in ancient Greece that did not occur in the cultures of Asia or Africa, and it is here that he runs afoul of charges of Eurocentrism. In the wake of certain historical developments, the Greeks began to call into question their time-honored beliefs, customs and traditions.

\footnotetext{
${ }^{7}$ See Hegel (1977, p. 261); Hegel (1928 - 1941, vol. 2, p. 333).
} 
A part of this had to do with the development of Greek science, which provided an alternative explanation for natural phenomena, thus undermining the religious view that the gods were the cause of, for example, earthquakes, volcanic eruptions, plagues, and so forth. It was regarded as sacrilegious when some of the Pre-Socratic philosophers such as Anaxagoras claimed that the heavenly bodies were not gods but rather natural substances, the sun being a fiery piece of metal and the moon a giant clod of earth. This started to sow the seeds of doubt about the older way of understanding the world.

Hegel argues that Socrates was the first person explicitly to call into question the traditional order of things, and, by doing so, he pointed to a new principle of thought. ${ }^{8}$ The Greek philosopher demanded that the customs and traditions of ancient Athens be grounded in discursive reason, and he refused to grant his assent before this justification was provided. He went around Athens asking people to justify their beliefs and ground their views, and his critical questioning led them to despair when they could not do so consistently. Socrates thus made the objective order of things the object of critical examination. For something to be objectively true, it needed to be scrutinized and approved by the individual. Thus, the objective began to give way to the subjective. This was, of course, a sensitive matter since people lived their lives according to these old beliefs and customs, and it understandably made them nervous to see these traditional ways of thinking called into question.

Perhaps most troubling for the Athenians was that Socrates seemed to posit a new criterion for truth by appealing to his well-known "daimon," the voice in his head that warned him against doing certain things (Hegel 1995, vol. 1, pp. 421 - 425; Hegel 1928 - 1941, vol. 18, pp. 94 - 100). In the Greek world this was particularly offensive and even sacrilegious. As is well known, there was a very ancient practice of consulting public oracles, like the famous one at Delphi, when important decisions had to be made. In this way the politicians and generals could assure themselves that their decisions were in harmony with the will of the gods and the natural order. The implicit idea was that, as individuals, people have only limited knowledge and agency. They cannot make important decisions on their own but instead need the help of the god Apollo, who would speak to them through the priestess at the oracle. The individual alone was thought to have no authority and to need this help. With Socrates this traditional conception was entirely inverted: he claimed to be in contact with a god directly. He asserted, in essence, that he had his own private divinity. The locus of the divine was not a public sanctuary or temple but the inner recesses of the mind of a single man. Thus, the content of the divine message could not be publicly accessed or scrutinized. When

\footnotetext{
${ }^{8}$ For Hegel's account of Socrates, see Hegel (1995, vol. 1, 384 - 448); Hegel (1928 - 1941, vol. 18, 42 - 122).
} 
Socrates appealed to his daimon to justify his actions, which were perceived as contrary to accepted custom and practice, he was effectively saying that his personal views were higher than the time-honored customs and traditions of the state; his personal deity had more authority than the gods of Athens. Thus, one of the charges leveled against him was that he worshiped gods different from those accepted by the state.

According to Hegel, Socrates set into motion a long historical process whereby the locus of truth gradually shifted from the objective sphere to the subjective one (Hegel 1991, § 138, pp. 166 - 167; Hegel 1928 - 1941, vol. 7, pp. 198 - 200). The inward sphere of the individual comes to be recognized as something important and valuable in its own right. Now it is thought that individuals can make their own decisions based on their own judgment and authority. Thus, the characteristic of the modern world is the principle of what Hegel calls subjective freedom. In the modern world there is a certain skepticism about the idea that the truth lies in external customs, traditions, laws, etc. These, we believe, are merely arbitrary constructs, created for ad hoc purposes at specific times. On the contrary, the true modern locus for truth is the individual human mind. This is what is truly infinite and divine. The goal on this view is thus to liberate oneself from the shackles of tradition and discover the truth which lies within oneself. For Hegel, the story of Western history is that of the discovery and development of the idea of subjectivity and individuality, as the human mind gradually comes to realize its own value and importance.

\section{The Modern World and the Principle of Subjectivity}

As the value of the individual subject comes to be understood in the modern world, this has important consequences for the different cultural spheres. The story of modern philosophy, it is said, begins not with the world but with the subject. Hegel thus analyzes Descartes' famous cogito argument in terms of this shift (Hegel 1995, vol. 3, pp. 220 252; Hegel 1928 - 1941, vol. 19, pp. 331 - 367). Descartes claims that the indubitable first principle of all thought is that of one's own existence. Only after this has been established is it possible to go on and determine the existence of the external world. Descartes thus gives priority to the subject, that is, one's immediate awareness of oneself, and the external world is something secondary and derivative.

This principle was developed in more detail by Kant with his famous "Copernican turn" in philosophy (Hegel 1995, vol. 3, pp. 423 - 478; Hegel 1928 - 1941, vol. 19, pp. $551-611)$. Kant argued that the assumption of the metaphysicians was always that our representations conformed (or should conform) to preexisting objects in the outside world. But Kant reverses this by claiming that those objects must necessarily conform to the representations produced by the categories of the human mind. In other words, what we understand as objectivity is a product of the human perceptual and cognitive 
apparatus, without which objects in the world would not be discrete, circumscribable or coherent in any way. He likens this new principle to Copernicus' revolution in astronomy with the replacement of the geocentric model with the heliocentric one. Kant's transcendental philosophy, so to speak, places the human subject and not the object sphere at the center of things.

This principle was made even more extreme by Fichte with his theory of the selfpositing ego, which like Descartes' cogito, begins with the human subject and deduces the world from that point of departure (Hegel 1995, vol. 3, pp. 479 - 506; Hegel 1928 - 1941, vol. 19, pp. 611 - 641). Fichte understands the human subject, which he calls the "I" or the "ego," to have immediate knowledge and access to itself, and then the external world and everything else is simply what is opposed to it, what he calls the "not-I." Once again, priority is given to the human subject, and the sphere of objects is only secondary.

According to Hegel, the German Romantics, such as Friedrich von Schlegel, can be seen as a further development of this tradition (Hegel 1995, vol. 3, pp. 507 - 508; Hegel 1928 - 1941, vol. 19, pp. 642 - 644). Specifically, they take Fichte's epistemological principle of the self-positing ego and turn it into a principle of ethics and aesthetics. They believe that Fichte's theory gives them license to reject all customs, traditions and laws that do not suit them. One might think of Schlegel's novel Lucinde, with its rejection of bourgeois notions of social respectability and love in the context of marriage. The Romantics believe they can construct or create their own world out of their subjectivity, and the world as they find it has no validity whatsoever. They thus celebrate the liberation of the individual and develop a cult of genius.

Also in the sphere of theology and religion the movement from the objective to the subjective is clearly discernible. Hegel traces the religions of the world and argues that they can be seen as leading teleologically to Christianity, which represents the culmination of religious thinking. According to his interpretation, only Christianity fully recognizes the inward nature of the human being. The Christian idea of being created in the image of God, for example, played an important role in the development of the opposition to the institution of slavery in the Roman world. To take another example, the God of Judaism commanded obedience on threat of severe punishment, in effect issuing a simple power claim: do this or else. For Hegel, this fails to recognize the rational element in human beings. There is no attempt made to persuade the people to do something by appeal to their reason. Instead, the God of the Old Testament treats people as if they were children lacking this faculty. By contrast, the message of Christianity is one that focuses specifically on the inwardness of each individual. Christ tells his followers that sin is not in their outward actions but in their inner conscience. 
The Reformation was also of crucial importance. Luther rejected the authority of the Church, the pope, and the clergy and placed the responsibility for religious belief in the conscience of each individual (Hegel 1995, vol. 3, pp. 146 - 155; Hegel 1928 1941, vol. 19, pp. 253 -262). Each person was responsible for his or her own belief based on his or her own reading of the Bible. The dogmas were of course still important, but they needed to be appropriated by each person individually instead of being dictated to them ex cathedra. Again the rational, inward element of the individual is recognized and valued in a way that was not the case previously. For Hegel, this was an important step in the development of individuality. The entire movement of Protestantism can be seen as a shift from the objective to the subjective.

In light of the important scientific developments of the $16^{\text {th }}, 17^{\text {th }}$ and $18^{\text {th }}$ centuries, the Enlightenment issued a harsh criticism of religion, the key doctrines of which seemed wholly incompatible with the new scientific understanding of the world. In response to this Schleiermacher tried to rethink the fundamental categories of religion and, in the spirit of the Romantics, turned the focus to the inward sphere (Hegel 1995, vol. 3, pp. 508 - 510; Hegel 1928 - 1941, vol. 19, p. 644). ${ }^{9}$ Instead of trying to demonstrate the objective existence of God in the world by means of the traditional arguments, Schleiermacher claimed that the origin of the divine was to be found in inward feeling or intuition. He argues that, regardless of what religion or denomination one adheres to, the notion of God comes from a fundamental form of immediate selfconsciousness that he refers to as "the feeling of absolute dependency" (Schleiermacher 1999, § 4, pp. 12 - 18; Schleiermacher 1830 - 1831, vol. 1, § 4, pp. 16 - 24). In other words, as finite human beings, we all have a natural feeling of vulnerability and being dependent on something greater than ourselves, and this is the origin of the conception of God, from which all the other dogmas are subsequently developed. Thus, the locus of the divine is not somewhere out there in the universe, but in the individual subject. Although for obvious reasons it is not a part of Hegel's analysis, it can be said that Søren Kierkegaard follows in this tradition by putting the focus squarely on the individual subject and denying the idea that facts from the objective sphere can play any role whatsoever in the faith of the individual. On this view, history, science, and philosophy are all entirely irrelevant for the inward faith of the individual.

In literature one can see a similar development from the sphere of the objective to that of the subjective. In the epic poetry of the ancients the focus is on the external actions and large-scale events: the Trojan War, Odysseus' journey back home to Ithaca,

\footnotetext{
${ }^{9}$ See also Hegel's foreword in Hinrichs (1822, pp. i-xxviii); Hegel (1928 - 1941, vol. 20, pp. 1 28); Hegel (2002, pp. 332 - 353). For accounts of Hegel's view of Schleiermacher's theology, see Crouter (2005, pp. 70 - 97). Glockner (1965, pp. $246-271)$.
} 
Aeneas' journey to Italy to found the line that would lead to Rome. Even though there are great individual heroes featured in these stories, the emphasis is on their outward actions and the events in the world. By contrast, after the development of Christianity, a new form of writing emerges, which focuses on the inward life of the individual, such as Augustine's Confessions. Now the genre of autobiography appears for the first time. Here the epic struggle is not something in the external world but rather takes place in the mind of the individual. While Dante self-consciously imitates Homer and Virgil, nonetheless the nature of his epic is fundamentally different. Unlike his predecessors, Dante has the audacity to cast himself in the leading role as the hero, the pendant of Achilles, Odysseus and Aeneas. The role of the individual as author thus increases dramatically. While Dante takes a great journey, like Odysseus and Aeneas, his journey is not one in the external world, but rather it is allegorical, the story of his own inward spiritual development. Here we can see a new recognition of the value of the individual that did not exist previously and that was further developed in modern literature. Thus, for Hegel, the story of modern history is about the development of the sphere of individuality and subjectivity. This principle had clearly won the day by his own time.

It should be noted once again that Hegel's thinking is always dialectical, and the story he wants to tell about the historical movement from objectivity to subjectivity is always one of degree or emphasis. While the emphasis in the ancient world was on the objective side, the emphasis of the modern is on the subjective. But in both cases the opposite principle is still present. This is important because, while Hegel celebrates the modern development of subjectivity, he at the same time believes that it has, in some contexts, gone too far in his own age. His criticism of figures such as Fichte, Jacobi, Schleiermacher, Friedrich von Schlegel and the German Romantics constantly returns to this point. ${ }^{10}$ They have taken the principle of subjectivity, emptied it of all content, and ended in relativism.

So clearly Hegel's account is not simply an encomium for modern subjectivity as such. Rather the key is to get the balance right between subjectivity and objectivity. Our modern subjectivity can lead to alienation, and relativism since we no longer feel any strong bond with the family, community or the state. These are important elements of the ancient world that need to be recovered in our modern times. The goal is thus to attain a situation that allows for the freedom of the individual, while at the same time not undermining tradition and custom that are valuable in forming the bonds between individuals.

${ }^{10}$ See, for example, Reid (2014); Stewart (2015, pp. $\left.272-281\right)$. 


\section{Hegel and the Emergence of Human Rights in the Modern World}

The idea of inalienable human rights can only emerge when the principle of subjectivity has come to fruition. In other words, when it is realized that human beings have a sense of inwardness and subjectivity that is valuable, then there naturally arises a need to preserve and protect this. While we often tend to associate the idea of inalienable human rights with the Enlightenment, for example, with the French "Declaration of the Rights of Man and Citizen" or the American "Declaration of Independence," in fact, the idea goes back much further.

It can be said to arise with the development of Christian thinking. Early Christian writers developed the idea that every individual has a soul and carries with him- or herself a part of the divine. According to the Christian view, Adam was merely a lifeless clod of clay until God breathed the breath of life into him (Hegel 1984 - 1987, vol. 2 , p. 522; Hegel 1983 - 1985, vol. 2, pp. 419f.). This breath or "spirit" was the principle of life, and it was thus given by God. So all human beings are thought to possess this divine spark. This idea thus radically elevates the idea of what it is to be human. It further grounded the Christians' radical opposition to the idea of slavery, which was so prevalent in the Greco-Roman world.

Similarly, in order to make sense, the idea of human rights assumes a certain conception of human freedom and agency. To say that humans have the right to "liberty" and the "pursuit of happiness," as is written in the American Declaration of Independence implies that humans have the ability to act freely and autonomously in the world. While this seems obvious to our intuitions today, this was not always the conception of human beings and human agency.

In the ancient world, the idea of humans resembled in some ways our idea of children. They first had to consult the gods before acting. They did not perceive themselves as capable of determining their own actions. What we regard as key human characteristics such as prudence and conscience were not thought to belong to human beings but rather to the gods. In the Iliad, Achilles shows prudence by refraining from drawing his sword against Agamemnon, but the prudence does not come from his own inner rationality (Hegel 1984 - 1987, vol. 2, p. 478; Hegel 1983 - 1985, vol. 2, p. 378). ${ }^{11} \mathrm{He}$ does not restrain his anger on his own by means of self-control, but instead, he is physically prevented from drawing his sword by the goddess Athena who swoops down at the last minute. Similarly, Orestes has no conscience on his own, after having killed his mother to avenge the murder of his father. Instead, he is plagued by the Erinyes, the deities who mercilessly pursue him and demand justice by denying him any rest. Thus, the idea of a human conscience had still not yet arisen.

\footnotetext{
${ }^{11}$ See also Hegel (1944, p. 236); Hegel (1928 - 1941, vol. 11, p. 311). See Homer (1951, Book I, p. 64 , lines $188-198)$.
} 
Conscience was thought to come from an external source (Hegel 1984 - 1987, vol. 2, p. 479; Hegel $1983-1985$, vol. 2, p. 379). ${ }^{12}$ These episodes demonstrate a radically different conception of the human being from the one we have today. On this view, humans are impetuous and act according to their immediate natural impulses. They have no reflective rational faculty of prudence or conscience.

To ascribe rights to people implies that they are capable of exercising them in a rational way. But if they are lacking certain basic capacities, then the idea itself collapses. We do not extend, for example, voting rights to children since it is clear that they have not yet developed the ability to make use of such a right meaningfully. Similarly the faculties of prudence and conscience are not something that children are born with. They need to be developed over a period of time through their upbringing and education.

Thus, on Hegel's view the very notion of human rights is one that arises simultaneously with the emergence of the awareness of human subjectivity and freedom. $\mathrm{Hu}-$ man rights are thus firmly grounded in a conception of anthropology. Only when humans come to be conceived of in a specific way can the idea of rights emerge. This is, of course, not to say that this account can be seen as Hegel's attempt to ground humans rights as such. That would involve a much broader discussion for which the Philosophy of Right would be the relevant text. The claim of this paper is merely that this account of the development of the conception of the human is a necessary condition for the idea of human rights to arise in the first place.

Hegel's theory can, however, be insightful for discussions about the nature and origin of human rights. On the one hand, human rights are not immediate facts of nature as Antigone believed. They are not divinely given, natural laws. This picture denies the individual the right to consent and simply obliges one to action as if by divine command. It thus fails to recognize the inwardness and subjectivity of the individual. On the other hand, human rights are not simply an abstract, arbitrary convention that is handed down from above by politicians and jurists, as some ethical skeptics would assume. Instead, they arise as a natural growth from the human mind itself. The idea emerges in history as the human mind develops. But this is not an arbitrary development any more than the development from a child to an adult is arbitrary. It is a rational idea that arises at a specific time and place in the historical development, thus forming a part of the story that Hegel wants to tell about world history. Human rights reflect the rationality of human beings.

Hegel's claim here is of course not the simple historicist one that argues that since a specific law or institution arose in history and has a certain tradition, it is ipso facto

\footnotetext{
${ }^{12}$ See also Hegel (1984 - 1987, vol. 2, p. 646); Hegel (1983 - 1985, vol. 2, p. 538).
} 
true and just. In fact, this is exactly the kind of argumentation that Hegel rejects when he criticizes the historicist school of law in the Philosophy of Right. Just because something arose historically and continues to exist is no guarantee of anything (Hegel 1991, § 3, p. 29; Hegel, 1928 - 1941, vol. 7, 43f.). On the contrary, if a specific law or institution was created at a certain point in the past under certain conditions, there is every reason to be suspicious that, with the passage of time and the changing of conditions, the same law or institution might today have completely lost whatever legitimacy it might have had. So clearly Hegel's point is not that since the idea of human rights arose under certain conditions at a specific time in history, they should be regarded as true and valid. The idea itself is true and has its validity in its rationality, independent of any specific historical period. But in order for this rationality to be realized, humans must have attained a certain level of rationality themselves.

The details of this must of course be elaborated in the context of another article that would take the Philosophy of Right as the point of departure. The point of the present article is simply to indicate that such a discussion about human rights begins for Hegel much earlier in a theory of history and philosophical anthropology. In this article I have confined myself to showing that Hegel beleves that the historical development of human freedom is the condition for the idea of human rights to emerge.

\section{Bibliography}

BERNASCONI, R. (1998): Hegel at the Court of the Ashanti. In: Barnett. S. (ed.): Hegel after Derrida. New York: Routledge 1998, $41-63$.

BERNASCONI, R. (2000): With What Must the Philosophy of World History Begin? On the Racial Basis of Eurocentrism. Nineteenth-Century Contexts, 22, $171-201$.

BERNASCONI, R. (2007): The Return of Africa: Hegel and the Question of the Racial Identity of the Egyptians. In: Grier, Ph. (ed.): Identity and Difference: Studies in Hegel's Logic, Philosophy of Spirit and Politics. Albany: State University of New York Press, $201-216$.

BRICMONT, J. (2007): Humanitarian Imperialism: Using Human Rights to Sell War, Dehli: Aakar Books.

BUCHWALTER, A. (2013): Hegel, Human Rights, and Political Membership. Hegel Bulletin, 34 (1), $98-119$.

BUTLER, C. (2008): Human Rights Ethics: A Rational Approach. West Lafayette. In: Purdue University Press.

CAMARA, B. (2005): The Falsity of Hegel's Theses on Africa. Journal of Black Studies, 36 (1), 82 - 96.

CROUTER, R. (2005): Friedrich Schleiermacher: Between Enlightenment and Romanticism. Cambridge et al.: Cambridge University Press.

DORFMAN, B. (2014): Are Human Rights a Philosophy of History. The Case for the Defense. International Social Science Review, 18 (1) 1 - 35.

DOUZINAS, C. (2002): Identity, Recognition, Rights or What Can Hegel Teach Us about Human Rights? Journal of Law and Society, 29 (3), $379-405$. 
GLOCKNER, H. (1965): Hegel und Schleiermacher im Kampf um Religionsphilosophie und Glaubenslehre. In: his Beiträge zum Verständnis und zur Kritik Hegels sowie zur Umgestaltung seiner Geisteswelt, Bonn: Bouvier 1965 (Hegel-Studien, Beiheft 2) 246-271.

HEGEL, G. W. F. (1928 - 1941): Sämtliche Werke. Jubiläumsausgabe. Vols. 1 - 20. Glockner H. (ed.). Stuttgart: Friedrich Frommann Verlag.

HEGEL, G. W. F. (1944): The Philosophy of History. Trans. by Sibree, J. New York: Willey Book Co.

HEGEL, G. W. F. (1977): Hegel's Phenomenology of Spirit. Trans. by Miller, A. V. Oxford: Clarendon Press.

HEGEL, G. W. F. (1983 - 1985): Vorlesungen über die Philosophie der Religion. Parts 1 - 3. Jaeschke, W. (ed.). Hamburg: Felix Meiner.

HEGEL, G. W. F. (1984 - 1987): Lectures on the Philosophy of Religion. Vols. 1 -3. Trans.: Brown, R. F. -Hodgson, P. C. - Stewart, J. M. with the assistance of Harris, H. S. Berkeley et al.: University of California Press.

HEGEL, G. W. F. (1989): Hegel's Science of Logic. Trans.: Miller, A.V. London: George Allen and Unwin.

HEGEL, G. W. F. (1991): Elements of the Philosophy of Right. Trans.: Nisbet, H. B. Cambridge New York: Cambridge University Press 1991.

HEGEL, G. W. F. (1995): Lectures on the History of Philosophy. Vols. 1 -3. Trans.: Haldane, E. S. Lincoln - London: University of Nebraska Press.

HEGEL, G. W. F. (2002): Foreword to Hinrichs' Religion in Its Inner Relation to Science. In: Miscellaneous Writings by G. W. F. Hegel. Stewart J. (ed.). Evanston - Illinois: Northwestern University Press, $332-353$.

HINCHMAN, L. P. (1984): The Origins of Human Rights: A Hegelian Perspective. Western Political Research Quarterly, 37 (1), 7 - 31.

HINRICHS, H. F. W. (1822): Die Religion im inneren Verhältnisse zur Wissenschaft. Heidelberg: Karl Groos.

HOFFHEIMER, M. H. (2001): Hegel, Race, Genocide. Southern Journal of Philosophy, 39 (supplement), $35-62$.

HOFFHEIMER, M. H. (2005): Race and Law in Hegel's Philosophy of Religion. In: Race and Racism in Modern Philosophy. Valls, A. (ed.). Ithaca-London: Cornell University Press, 194 - 216.

HOMER (1951): The Iliad of Homer. Trans.: Lattimore, R. Chicago - London: University of Chicago Press.

HONNETH, A. (1995): The Struggle for Recognition: The Moral Grammar of Social Conflicts. Trans.: Anderson, J. Cambridge: MIT Press.

HONNETH, A. (2012): The I in We: Studies in the Theory of Recognition. Trans.: Ganahl, J. Cambridge (UK) - Malden (MA): Polity Press.

IBHAWOH, B. (2007): Imperialism and Human Rights: Colonial Discourses of Rights and Liberty in African History. Albany: SUNY Press.

KIERKEGAARD, S. (1989): The Concept of Irony; Schelling Lecture Notes. Trans.: Howard V. Hong, Edna H. Hong. Princeton: Princeton University Press.

MALETZ, D. J. (1989): Hegel on Right as Actualized Will. Political Theory, 17 (1), 33 - 50.

MULLENDER, R. (2003): Hegel, Human Rights and Particularism. Journal of Law and Society, 30 (4), $554-574$.

REID, J. (2014): The Anti-Romantic: Hegel Against Ironic Romanticism. London: Bloomsbury. 
SCHLEIERMACHER, F. D. E. (1830 - 1831): Der christliche Glaube nach den Grundsätzen der evangelischen Kirche im Zusammenhange. Vols. 1 -2. Berlin: G. Reimer.

SCHLEIERMACHER, F. D. E. (1999): The Christian Faith. Trans. Macintosh H. R., Stewart, J. S. Edinburgh: T. \& T. Clark.

SMITH, S. B. (1989): What is "Right" in Hegel's Philosophy of Right? The American Political Science Review, 83 (1), 3 - 18.

SOPHOCLES (1960): Antigone, in Sophocles I. In: Grene, D. - Lattimore, R. New York: Random House 1960.

SÖDERQUIST, K. B. (2012): Contemplative History vs. Speculative History: Kierkegaard and Hegel on History in On the Concept of Irony. Kierkegaard Studies Yearbook, $101-116$.

STEWART, J. (2011): Hegel's Historical Methodology in The Concept of Irony. Kierkegaard Studies Yearbook, $81-100$.

STEWART, J. (2015): Hegel's Criticism of the Enlightenment and Romanticism: The Problem of Content in Religion. Filozofia, 70 (4), $272-281$.

STILLMAN, P. G. (1980): Hegel's Civil Society: a Locus of Freedom. Polity, 12 (4), 622 - 646.

TAYLOR, C., GUTMAN, A. (1994): Multiculturalism: Examining the Politics of Recognition, Princeton: Princeton University Press.

TIBEBU, T. (2011): Hegel and the Third World: The Making of Eurocentrism in World History, Syracuse: Syracuse University Press.

This work was produced at the Institute of Philosophy, Slovak Academy of Sciences. It was supported by the Slovak Research and Development Agency under the contract No. APVV-15-0682.

\author{
Jon Stewart \\ Institute of Philosophy \\ Slovak Academy of Sciences \\ Klemensova 19 \\ 81364 Bratislava \\ Slovakia \\ e-mail: js@jonstewart.dk
}

